\title{
Game theory and why logic may not be very "Logical."
}

\author{
Niall Heffernan
}

School of English, UCC

"Woe to those who, to the very end, insist on regulating the movement that exceeds them with the narrow mind of the mechanic who changes a tire." (Georges Bataille, The Accursed Share)

\section{Introduction}

At the end of Stanley Kubrick's masterpiece Dr Strangelove: Or How I Learned to Stop Worrying and Love the Bomb, Major 'King' Kong rides the nuclear bomb to oblivion. The chosen few deep underground in the American War Room have ascertained that the Soviet's "Doomsday Machine" will automatically retaliate and enshroud the earth in a cloud of radioactive material for 100 years. The pristine logic of the Cold War that culminated in Kong riding the bomb in the film, and brought the world to the edge of oblivion with the Cuban Missile Crisis of 1962, is based on game theory. Strangelove is the first popular film or fiction to deal with game theory, and does so with great attention to detail. Thus, it is an excellent starting point for historical insight into the beginnings of what has recently been described in The New Palgrave: A Dictionary of Economics as a 'unified theory'. Game theory is, to state it simply, a mathematical formulation of strategic thinking in competitive situations. If the world is viewed in simplified Darwinian terms, such as 'survival of the fittest,' it becomes clear why game theory is now seen as a unified theory. If the world runs on competition, then the general and 'objective' maths of game theory can be, and are, applied to everything from biology to economics to war strategies. Despite its virtual ubiquity in the first world, little has been written of it critically. Its influence, however, has permeated the world of fiction, film and television in certain instances and some among these works, such as Strangelove, provide fascinating insights into the theory's workings and reception.

In the early 1960s the United States settled on a strategy of nuclear deterrence, with the tacit agreement of the Soviets, it would seem. The strategy was based upon the assumption that both agents involved were 'rational,' and thus the rational Soviets would not strike against the United States, as they couldn't possibly destroy all the U.S missiles. They would in turn be destroyed by the U.S. Counter-attack, and this, of course, was not in their own rational self-interest. Thus there was struck an 'equilibrium' between the two superpowers, upon which the fate of all species rested! This game theoretical strategy 
was known as Mutual Assured Destruction, or more commonly by its hilariously ironic acronym; MAD.

Kubrick famously set out to make a straight Cold War thriller loosely based on the Peter George novel Red Alert, but the absurdity of the situation became too much. Kubrick retained the attention to detail, however, and all of the logic of deterrence and many of the protocols seen in the film are exactly accurate.

\section{Two fathers of the Logic}

Game theory was first developed as a concerted theory in the 1940s by the HungarianAmerican mathematician John Von Neumann, upon whom Strangelove's character is mostly based. Von Neumann contributed to many fields of knowledge in mathematics, physics and more, but it is for his formulation of the 'minimax theorem' that he will be remembered. This theorem seeks to calculate the minimum maximum possible loss in a situation where two agents are in direct competition. This theorem fits the Cold War arms race perfectly.

The other 'father' of Game theory along with Von Neumann, is John Nash, who has been made much more famous than the former by the recent Ron Howard film A Beautiful Mind. Nash extended the theory with his 1952 doctoral paper, known as 'Nash's Equilibrium.' It seemingly proved that an untold number of 'rational' agents, all pursuing their own gain, did not lead to chaos but could instead lead to a point of equilibrium. This was taken as mathematical proof of Adam Smith's hidden hand, that the pursuit of selfish gain was the fundamental principle of an ordered society, that communal notions were false and that altruism does not exist. Capitalism, in the war of ideologies, was seen as the ordained (not the godless communists), and scientifically 'proven' political system.

Both Nash and Von Neumann worked for a military think tank in the 1950s and 60s called RAND Corporation, (RAND meaning research and development, was a title so dull, it was surely designed to stifle curiosity about its doings, which as a matter of fact, changed the world!) Many engineers, mathematicians, physicists and so on, became enthralled with the rationalist appeal of game theory. Numbers are, after all, 'immutable' i.e. they cannot be argued with. What began initially as a loose set of theorems regarding poker strategy was transformed into what is now called a 'unified theory,' incorporating its first application, nuclear strategy, and later economics, and today is used in everything from bureaucratic management systems to biology and zoology.

The Cuban Missile Crisis happened two years before Strangelove was released and the Secretary of Defence at the time, the ultra-rational Robert McNamara, has since stated that it wasn't logic and rationality that prevented nuclear war: Instead, he bluntly states, "we lucked out." While advocates of game theory, of whom there are very many (and 
undoubtedly it has many useful applications as a modelling tool in some areas of knowledge) would possibly argue that the holocaust happens in Strangelove because of imperfect information and human error, they will fail to see that this is precisely the point.

\section{What does this have to do with me?}

One may ask at this point; 'yes, but what does this really have to do with an English research project and what does this have to do with me?' And it would be a timely question as this article is necessarily brief and the subject is complex and potentially far reaching. Let me refer, then, back to Strangelove once more. At the end of the film, of course, there is a nuclear holocaust, despite the fact that it is neither the Soviets' nor the Americans' intentions to cause one. The absurdity in Kubrick's film stems from the fact that all the pristine mathematical logic of game theoretical deterrence has led to a nuclear holocaust. The notion that mathematical logic exists somehow, independently of the messy arbitrations of humanity in flux, and that we can 'rationally' organise society around its logic is absurd. In this regard, what branch of human study could be better equipped to deal with human foibles, messiness and indeterminacy than the study of English? These human factors are, after all, its raison d'etre!

The urge to circumvent human fallibility with immutable numbers is a folly that can be traced back to Enlightenment texts such as William Petty's Political Arithmetick (1690) (based upon Ireland) or Thomas Hobbes' mechanistic view of the world in Leviathan (1651). The notion that society can be managed and improved with science and reason is as strong as it ever was in the Enlightenment era, but in light of the historical knowledge we should have accrued since then, is an even bigger folly. In Straw Dogs, the English thinker John Gray viciously attacks this kind of attempt to circumvent so-called human fallibility with science or mathematics.

"These are not flaws that can be remedied. Science cannot be used to reshape humankind in a more rational mould. Any new-model humanity will only reproduce the familiar deformities of its designers. It is a strange fancy to suppose that science can bring reason to an irrational world, when all it can ever do is give another twist to normal madness. These are not just inferences from history. The upshot of scientific inquiry is that humans cannot be other than irrational."

While Gray seems delightfully brutal, his assertion that we cannot be rational could be rephrased simply thus: rationality is subjective. What is rational to do here in Ireland is not necessarily rational for an indigenous Brazilian tribe. This, of course could be applied on an individual basis too, if you like! Ironically, by its own standards, this renders game theory useless. Rationality, according to its own assumptions, is what the individual does to pursue his or her own advancement in any given situation. All else is dismissed from 
its assumptions. James Buchanan, the American political theorist who developed 'Rational Choice Theory' (a game theoretical management system), dismissed what he called relative terms such as 'patriotism' or 'common good,' upon the basis of which old bureaucracies were run, as relative, or subjective, thus meaningless terms. How can 'rationality' be deemed a fixed, universal 'truth' while 'common good' is dismissed as too subjective to be meaningful?

It is very important to note here, that these assumptions of selfishness are synthesised from those of the theorists, as well as their intellects, which are in turn absolutely beholden to their personalities and their surrounding political environments. Von Neumann, for example, was self-described as "violently anti-communistic and much more militaristic than the norm," while also apparently being possessed of a compulsion to commit adultery. Trite correlations between Von Neumann's sexual compulsions and his fetish for missiles aside, the virulent anti-communism that was rife at the time, particularly among those who worked on Cold War strategy, fuelled the radical individualism at the heart of his theory's assumptions, as this was misguidedly seen as somehow 'opposite' to communism's doctrine.

In answer, briefly, to the second part of the question posed above (i.e., what does all this mean to me) I will ask you to think about the performance target. As adults who have probably been employed in recent years, we are surely all familiar with them. They are part of a broader management system known as 'systems analysis' and are statistically derived target-numbers that employees have been asked to fulfil, within the remit of their employment. Essentially, it is the modelling of the workplace on the competitive arena of free-market capitalism. Again, it is based on the assumption that humans are fundamentally self-motivated. In 'owning' your target, so to speak, you are motivated by your fundamental selfishness to be more productive. This is the management model by which the vast majority of bureaucracies, corporations and institutions are run nowadays, along with systems analysis and the emerging Public Choice Theory in politics.

\section{Society is shaped by its organising systems}

Although vastly different to Dr Strangelove, the recent television series The Wire offers a contrary view of the performance target. In its depiction of the municipal institutions of the U.S. City of Baltimore, the performance target does not bring about efficiency and rationality. Instead, the statistics are constantly manipulated, in a self-fulfilling realisation of the system's assumptions of individualistic greed, engendering institutional corruption.

In light of recent sociological findings about the huge effect environment has on collective and individual behaviour, as popularised by Malcolm Gladwell in Tipping Point, or the more heavyweight Systems, Not People make society Happen by Michael King, these texts suggest a problem of self-fulfilment in these systems that now rule our world. If society is 
organised around the tenets of selfishness and greed, this is what people will try to adapt to.

\section{New paradigms to live well together?}

If the study of English is the desire to know ourselves and each other, it is surely an arena to bridge the non-existent gap between human 'flaws' and pristine 'logic.' There is no such opposition. Nor is there an opposition between science and English, both are constructs of human activity. There are only human foibles, messiness and indeterminacy, which should be factored into our paradigms of how to live well together instead of being denied. The poetic indeterminacy of life may be lost in the quantitative valuation of ever more realms of our lives, in terms of dollar value, unless we embrace the limits of our logic.

With appreciation and gratitude to my co-supervisors Dr. Gwenda Young and Dr. Alan Gibbs, who have been patient, intuitive and excellent in their support. 